УДК 616-006.3

(C) 2014

Кулинич С. М., доктор ветеринарних наук

Полтавська державна аграрна академія

\title{
ЕФЕКТИВНІСТЬ КРІОДЕСТРУКЦІї У ВЕЛИКОЇ РОГАТОЇ ХУДОБИ В РАЗІ ВИДАЛЕННЯ ЗЛОЯКІСНИХ НОВОУТВОРЕНЬ ПОВІК
}

\section{Рецензент - доктор ветеринарних наук А. А. Замазій}

3'ясована симптоматика злоякісних новоутворень повік у великої рогатої худоби, опрацьований метод кріодеструкиї злоякісних новоутворень повік у великої рогатої худоби. Встановлена ефективність проведених процедур у післяопераџійний період за динамікою клінічних, а також морфологічних показників крові. Планіметричними дослідженнями встановлено, шзо до 15-ї доби зменшення ранового дефекту відносно вихідних показників становило 58,0\%, а на 20-y добу рубиі були ледь помітні цे становили лише $11,1 \%$ відносно початкових даних.

Ключові слова: рідкий азот, злоякісні пухлини, морфологічні дослідження крові.

Постановка проблеми. Кріохірургія (гр. kryos (холод) + хірургія) - сукупність хірургічних методів лікування, що базуються на локальному заморожуванні тканин [5].

Лікарі ветеринарної медицини методам кріодеструкції надають недостатньо уваги. У вітчизняній і зарубіжній літературі зустрічаються лише поодинокі рекомендації щодо його клінічного застосування, передусім у порівняльному аспекті з іншими методами лікування [1]. А між тим кріохірургічний метод володіє цілою низкою переваг і тому вважається досить перспективним для лікування онкологічних і терапевтичних захворювань [4].

Кріодеструкція, або видалення новоутворень рідким азотом, - це один із найпоширеніших методів боротьби 3 новоутвореннями. Метод цей досить розповсюджений, у багатьох випадках він $\epsilon$ незамінним, однак водночас має чимало недоліків.

Зокрема, під час заморожування тканини рідким азотом пацієнт може відчувати легкий дискомфорт, печіння або незначні больові відчуття, що досить швидко минають. Після припікання азотом ділянка стає малочутливою до зовнішніх подразнень, виникає невеликий набряк. Можлива поява невеликих пухирців на місці опіку протягом доби після припікання азотом. Протягом наступних кількох тижнів відбувається повне відторгнення тіла новоутворення, а на місці кріодеструкції залишається малопомітна пляма, яка зникає внаслідок повного оновлення клітин шкіри.
Аналіз основних досліджень і публікацій, у яких започатковано розв'язання проблеми. Американський лікар Ірвінг Купер відомий як творець першого в медицині кріохірургічного інструмента. До його створення Купера підштовхнув його різдвяний подарунок - пристрій, за допомогою якого відкорковувалися пляшки з вином.

Історія зберегла навіть дату цього важливого моменту - 25 грудня 1960 року. У пристрої відкорковувача для вина використовувався вуглекислий стиснений газ, який вводився через голку в проколи пробки пляшки. Медик зазначив, що струмінь виведеного газу був досить холодним. Окрім того він спробував спрямувати струмінь на долоню й отримав дивний результат - на долоні утворювалися крижані кристали, а ефект заморожування мав локальний характер. Подібний принцип був використаний Купером у його винаході. Робоча частина інструмента представляла собою тонку трубку, по якій протікав рідкий азот. Подібний інструмент американський лікар використовував у нейрохірургії, під час операцій із видалення пухлин головного мозку. Таким чином, авторство щодо застосування рідкого азоту в операції на головному мозку належить лікареві Ірвінгу Куперу [6].

У ветеринарній медицині лікування патологічних процесів рідким азотом почали використовувати значно пізніше. Зокрема В. П. Вайткус застосовував його у процесі лікування тіломи у великої рогатої худоби, І. Ф. Вілковський - під час лікування пухлин печінки в собак $[2,3]$.

Мета дослідження: встановити у корів ефективність кріодеструкції плоскоклітинної карциноми повік.

Завдання дослідження: опрацювати оперативну техніку та встановити ефективність проведених маніпуляцій у післяопераційний період.

Матеріали та методи дослідження. Дослідження були проведені в період 2012-2013 років. Для проведення досліду були відібрані корови, які належали мешканцям Полтавського району. У тварин під час проведення клінічного огляду були діагностовані злоякісні новоутворення, які 


\section{ВЕТЕРИНАРНА МЕДИЦИНА}

після седації та місцевого знеболення були видалені з подальшим проведенням кріодеструкції.

Для заспокоєння тварин внутрішньовенно (яремна вена) вводили 1 мл препарату Ксила (Interchemie Werken «de Adelaar» BV, Нідерланди). Після седації тварин проводили інфільтрацію тканин повіки $0,5 \%$ розчином новокаїну, витрачаючи на тварину 40-50 мл розчину.

Основну масу бластоми зрізали ножицями Купера, після чого зупиняли кровотечу притисканням великих $(15 \times 12$ см) стерильних ватномарлевих серветок. Лише після цих процедур проводили кріодеструкцію тканин. 3 цією метою використовували рідкий азот, температура кипіння якого становила $-196{ }^{\circ} \mathrm{C}$; його доставляли та зберігали в посудині Дюара на 5 літрів.

Речовину до місця обробки доставляли за допомогою довгого корнцангу який на 10-15 секунд для охолодження занурювали у відкриту посудину з рідким азотом. Охолоджений корнцанг притискали до пухлини до утворення білої крижаної оболонки навколо тампона.

Перший раз рідкий азот наносили одноразово й не більше ніж на 5 секунд, оскільки може позначатися підвищена чутливість до нього.

Під час виконання кріодеструкції спочатку захоплювали щонайменше 3 мм краю здорової шкіри та охолоджували. Під час обробки рідким азотом корцанг примерзав до обведених меж, захищаючи нормальну оточуючу тканину від пошкодження холодом.

Далі у процес заморожування залучалися все більш глибокі тканини. Кріодеструкцію проводили впродовж 15-20 хвилин.

За потреби на повіки накладали провізорний шов, який знімали через 7 діб. У післяопераційний період досліджували динаміку клінічних (кожну добу до одужання проводили планіметричні дослідження, що полягали у вимірюванні довжини ран за допомогою лінійки), а також мор- фологічних показників крові (перша, десята, п’ятнадцята доба).

Статистичну обробку результатів експериментальних досліджень проводили шляхом визначення середнього арифметичного (М), його похибки (m), рівня вірогідності (p) із використанням таблиці t-критеріїв Стьюдента. Зміни показників вважали вірогідними за $\mathrm{p}<0,05$.

Результати дослідження. Під час проведення хірургічної диспансеризації нами було виокремлено групу з п'яти корів, із діагнозом плоскоклітинна карцинома правої нижньої повіки. Під час клінічного огляду було встановлено, що в $100 \%$ випадків уражувалася нижня повіка правого ока, а також з'ясовано, що вона не давала метастазів, проте мала інфільтративний ріст.

Бластоми повіки діагностували у вигляді вузлового ущільнення або в двох випадках плоского бородавчастого утворення, яке нависало над поверхнею шкіри й частково закривало очне яблуко. На поверхні пухлини виявляли темно-коричневу або чорну кірку з прилиплими до неї шерстинками та часточками соломи, після зняття якої виявляли бластому з виразками зі щільними краями й горбистим дном.

Пухлина вростала в повіку, частково руйнуючи іiі. Внаслідок подразнення нижньої повіки спостерігали сльозотечу та гнійну ексудацію. Розмір пухлин становив 11-13 см вдовж та 8-9 см - вшир (рис. 1a).

Після видалення пухлин (рис. 1б) у післяопераційний період спостерігали зменшення ранових дефектів. Зокрема, аналізуючи отримані нами дані, можемо констатувати наступне, що на третю добу довжина рани (табл. 1) зменшилася на 9,6\%. Відповідно, на сьому добу зменшення становило $29,4 \%$, а вже на десяту $-35,8 \%$.

До 15-ої доби зменшення становило 58,0\% відносно початкових даних.

\section{1. Динаміка зменшення довжини ранового дефекту за час лікування (М士m)}

\begin{tabular}{|c|c|c|}
\hline \multirow{2}{*}{ Доба } & \multicolumn{2}{|c|}{ Довжина рани } \\
\cline { 1 - 3 } & см & $\%$ \\
\hline Перша & $12,6 \pm 1,8$ & 100 \\
\hline Третя & $11,4 \pm 2,2$ & 90,4 \\
\hline Сьома & $8,9 \pm 2,4$ & 70,6 \\
\hline Десята & $8,1 \pm 1,4$ & 64,2 \\
\hline П'ятнадцята & $5,2 \pm 1,6$ & 41,2 \\
\hline Двадцята & $1,4 \pm 1,6$ & 11,1 \\
\hline
\end{tabular}




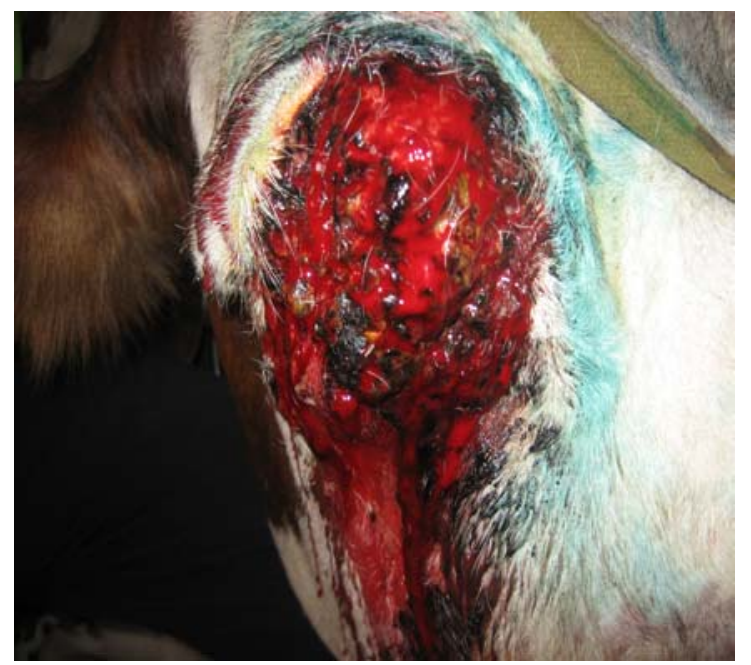

a

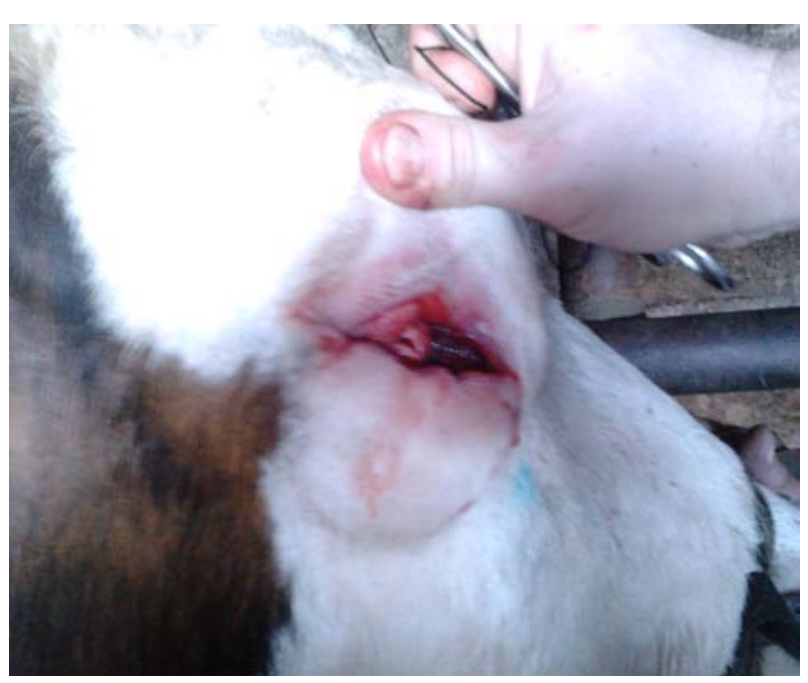

6

Рис. 1. Дослідна тварина (патологічне вогнище): а) до видалення пухлини; б) після видалення пухлини

2. Морфологічний склад крові прооперованих тварин (М士m)

\begin{tabular}{|c|c|c|c|}
\hline \multirow{2}{*}{ Показник } & \multicolumn{3}{|c|}{ Тварини $\mathrm{n}=5$} \\
\cline { 2 - 4 } & \multicolumn{3}{|c|}{ резекція вени } \\
\cline { 2 - 4 } & перша доба & 10 -а доба & 15 -а доба \\
\hline Лейкоцити, Г/л & $10,4 \pm 1,6$ & $11,3 \pm 1,2$ & $11,7 \pm 7,4$ \\
\hline Еритроцити, Т/л & $5,6 \pm 0,1$ & $5,8 \pm 0,9$ & $5,5 \pm 0,14$ \\
\hline Гемоглобін, г/л & $97,0 \pm 8,7$ & $98,0 \pm 14,8$ & $99,0 \pm 1,8$ \\
\hline
\end{tabular}

Під час проведення замірів на 20 -у добу рубці були ледь помітні й становили лише 11,1 \% відносно початкових даних.Згідно 3 поставленими нами завданнями, крім клінічних проводилися й лабораторні дослідження крові.

Аналізуючи отримані дані (табл. 2), можемо констатувати наступне: після виконання кріодеструкції пухлин на $10-\mathrm{y}$ добу реєстрували зростання кількості лейкоцитів на 8,6\%.

До п’ятнадцятої доби зазначена тенденція збереглася, відповідно їх чисельність наблизилась до верхньої межі норми й була на $12,5 \%$ вищою відносно вихідних даних.

Стосовно кількості еритроцитів та вмісту гемоглобіну слід зазначити, що до кінця терміну їх лікування показники суттєво не змінилися.

Отже, проведені нами морфологічні дослідження крові свідчать, що використання методу кріодеструкції пухлин супроводжується тенденцією до зростання кількості лейкоцитів.

\section{БІБЛІОГРАФІЯ}

1. Борисевич В. Б. Методи оперативного втручання 3 використанням кріогенних технологій. Мето-

\section{Висновки:}

1. Встановлено, що після першого охолодження в перші години виникає виражений запальний набряк як у місці кріодеструкції пухлини, так і в навколишніх тканинах, до того ж ділянка кріонекрозу через дві доби перетворюється в суху шкоринку, яка відділяється через $22 \pm 2,3$ доби.

2. Планіметричними дослідженнями встановлено, що до 15-ої доби зменшення ранового дефекту відносно вихідних показників становило $58,0 \%$, а на 20-у добу рубці були ледь помітні й становили лише 11,1 \% відносно початкових даних.

3. У випадках формування у корів плоскоклітинної карциноми повік, яка після оперативного видалення дає рецедиви, рекомендуємо після седації тварини проводити інфільтрацію тканин повіки $0,5 \%$ розчином новокаїну (40-50 мл розчину), основну масу бластоми зрізати ножицями Купера, після чого проводити кріодеструкцію пухлин рідким азотом упродовж 15-20 хвилин.

дичні рекомендації / [В. Б. Борисевич, В. П. Сухонос, П. К. Солонін та ін.]. - К., 2012. - 27 с. 


\section{ВЕТЕРИНАРНА МЕДИЦИНА}

2. Вайткус В. П. Применение жидкого азота при лечении тиломы у крупного рогатого скота / В. П. Вайткус, Б. А. Башкиров // Хирургические болезни сельскохозяйственных животных : сб. науч. тр. ЛВИ. - Ленинград, 1989. - С. 44-46.

3. Вилковыский И. Ф. Диагностика и лечение новообразований печени / И. Ф. Вилковыский // «Российский ветеринарный журнал. Мелкие домашние и дикие животные». - М. : Колос. 2006. - №1. - С. 14-17.

4. Сенчук А. Я. Органосохраняющая криохирургия предопухолевых заболеваний матки : доклад на Первой Междунар. науч.-практ. конф. [«Крио- хирургия. Современные методы и инновационные технологии»]. - 2007.

5. Криохирургия для животных. Какой рождественский подарок подтолкнул доктора Ирвинга Купера к изобретению? [Електронний ресурс]. Режим доступу : http://www.newcentury.ru/joom/ index.php?option $=$ com content\&view $=$ article $\&$ id $=$ $65 \% 3$ Avetcryo\&atid $=43 \% 3$ Avetnewspol $\&$ Itemid $=6$ 3\&lang=ru_6. http://otvetin.ru/naukatchech/9941kakoj-rozhdestvenskij-podarok-podtolknul-doktora. html 